\title{
蒸気圧を利用したトップヒート型熱輸送ループの開発研究* （熱輸送特性に関する基碟実験）
}

\author{
小系康 志*1, 堀内 康 洋*1, 山口 鉄 洋*1 \\ 井村 英昭*2, 鳥 居修一*1 \\ Development of a Top-heat-type Heat Transport Loop \\ Utilizing Vapor Pressure \\ (Fundamental Experiments on Heat Transport Characteristics) \\ Yasushi KOITO*3, Yasuhiro HORIUCHI, Tetsuhiro YAMAGUCHI, \\ Hideaki IMURA and Shuichi TORII \\ ${ }^{* 3}$ Department of Mechanical Engineering and Materials Science, Kumamoto University, \\ 2-39-1 Kurokami, Kumamoto-shi, Kumamoto, 860-8555 Japan

\begin{abstract}
A new top-heat-type heat transport loop has been constructed. It consists of a heated section, a cooled section, a reservoir, two valves and tubes connecting these components. Water is used as the working fluid. The heat is transported downward from the heated section to the cooled section by utilizing the vapor pressure of the working fluid. This paper explains the principle of operation and describes the fundamental experiments on the heat transport characteristics of the heat transport loop. The experimental results confirm that the temperatures and pressures inside the heat transport loop vary with cycles corresponding to the valve operation, and the heat is transported continuously by the small vapor pressure difference produced inside the heat transport loop. The effects of heat input to the heated section and cooling temperature of the cooled section are also discussed. The good point of this heat transport loop is that its thermal performance is hardly affected by the heat transport height.
\end{abstract}

Key Words: Heat Transport, Self-Operative, Top-Heat, Vapor Pressure, Experiment

\section{1. 緒}

通常の熱サイフォンは重力を利用して, 外部動力を 要することなく, 熱を上方に輸送する.これに対し, 熱サ イフォンを応用して熱を下方に輸送する場合, 凝縮器が 蒸発器よりも下方に位置するので, 重力に逆らって作動 液(凝縮液)を揚液する必要が生じる.このため, トップヒ 一ト型熱サイフォンと呼ばれる, 熱を下方に輸送する熱 サイフォンの開発に際しては, 作動液の揚液方法の考 案が必要とされ,これまでに, 著者らの研究レビュー(1) でも一部紹介したように, (1)毛細管力 ${ }^{(2)}$, (2)作動液の蒸 気圧 $^{(3)}{ }^{(7)}$, (3)蒸気泡の浮力 ${ }^{(8)}$, (9), (4)半透膜の浸透圧 (10) (12)を利用する揚液方法が考案されている.いずれの 方法も, トップヒート型熱サイフォンの開発に利用されて おり，その熱輸送特性に関する実験結果が種々報告さ

\footnotetext{
* 原稿受付 2005 年 8 月 12 日.

*1 正員, 熊本大学工学部 ( $860-8555$ 熊本市黑髮 2-39-1).

*2 正員, フェロー, 熊本大学工学部.

E-mail : koito@gpo.kumamoto-u.ac.jp
}

れている.

しかしながら, 例えば, 発電効率の向上を目的として, 低所にある自然の冷熱源(河川水, 地下水, 海水)を利 用し, 高所に設置される太陽電池パネルを冷却するな ど, 熱輸送高さが比較的高い場合の外部動力を要しな い熱の下向き輸送について検討したところ, 著者らが検 討した範囲において,この種の応用に問題無く実用でき るトップヒート型熱サイフォンは開発されてないようである. 従来のトップヒート型熱サイフォンは, いずれも作動流体 の蒸発・凝縮潜熱を利用し, 蒸気流によって蒝発器から 凝縮器まで熱を輸送する. また, 同時に凝縮器から蒸発 器まで凝縮液を揚液する必要があるため, 熱輸送高さと 揚液高さはほぼ等しくなる. したがって, 前述の(1), (2)の 揚液方法を利用した従来のトップヒート型熱サイフォン は, 熱輸送高さが高くなると, 作動液の揚液高さも高くな るので, 蒸発器と凝縮器の圧力差が大きくなり,この結 果, この間の温度差も大きくなって, 熱輸送性能が低下 する. 一方, 前述の(3), (4)の揚液方法を利用した従来 
のトップヒート型熱サイフォンについては, 前者の場合, 熱源の負荷変動に対する対応が困難であること, 外部 エネルギー(電力)を消費すること, また後者の場合, 熱 輸送量が小さいこと, 半透膜が劣化することが問題点と して挙げられる.

本研究では, 熱輸送高さおよび熱源の負荷変動の 影響をほとんど受けずに, 外部動力を要することなく, 熱 を下方に輸送する熱輸送ループを新たに開発する。環 境への悪影響がなく, 安全性が高いことから作動液には 水を採用し, その蒸気圧を揚液に利用する熱輸送ル一 プを提案する. 熱輸送ループの実験装置を組み立て, 熱輸送特性に関する基礎実験を実施する.

\section{2. おもな記号}

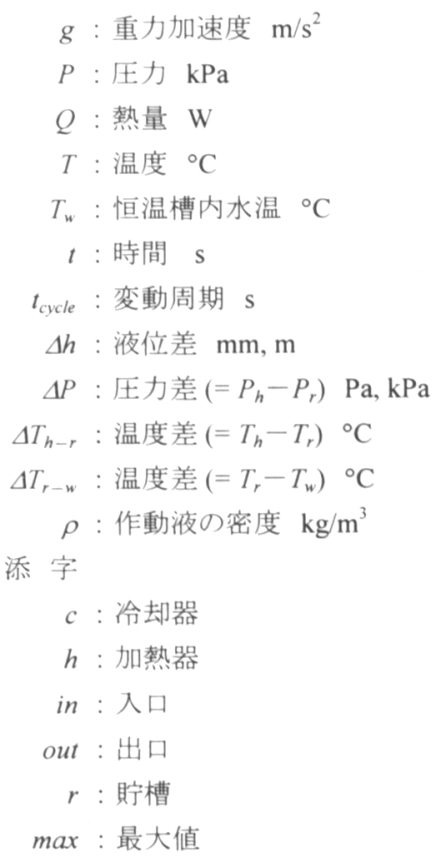

\section{3. 作動原理}

本研究で提案する熱輸送ループを図 1 に示した. 熱 輸送ループは, 加熱器, 冷却器, 貯槽, バルブ 1, バル ブ 2 およびこれらを連結する配管(液上昇管, 液下降管 等)から構成されており, 液上昇管側, 液下降管側ともに, 椧却器から加熱器上部の同じ高さまで作動液が封入さ れている. 温熱源の熱が加熱器に入熱され, 以下のよう に作動して, 泠却器で放熱される.

(i) 通常, バルブ 1 およびバルブ 2 は閉じており, 加 熱器への入熱に伴って, 加熱器内の作動液温度 および蒸気圧が高くなる.

( ii ) この結果, 加熱器内の作動液は液下降管内を通

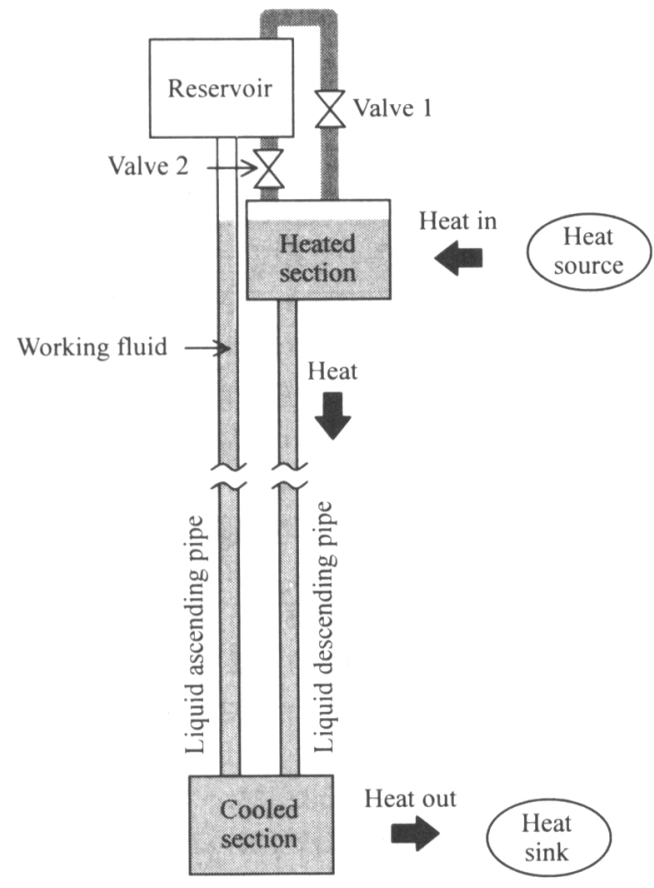

Fig. 1 Proposed top-heat-type heat transport loop

って冷却器へと押し下げられ，同時に熱も下方に 輸送される.また, 冷却器内で泠却された作動液 は液上昇管内を通って貯槽へと押し上げられ，貯 液される.

(iii) 加熱器内の液位が所定值まで低下すると, バル ブ 1 およびバルブ 2 が開き, 加熱器内と貯槽内 が等圧になるので, 重力により貯槽に貯液された 作動液が加熱器へと還流される.

(iv) バルブ 1 およびバルブ 2 が閉じ, 同様の作動が 繰り返される.

本熱輸送ループでは, 加熱器内の液面より以下は, 液上昇管側, 液下降管側ともに作動液で常時満たされ ており, 作動液の流動によって熱が下方に輸送される. したがって, 緒論で紹介した従来のトップヒート型熱サイ フォンと比較すると, 本熱輸送ループは, 作動液の顕熱 を利用して熱を輸送する熱輸送ループであるといえ,さ らに, 加熱器から貯槽までの高さが作動液の揚液高さと なるため, 熱輸送高さに対して, 揚液高さが非常に小さ いという特長を有する.

\section{4. 実験装置およひ実験方法}

実験装置を図 2 に示した。前述した作動原理に基づ 
いて製作したので, 実験装置は図 1 と同様に, 加熱器, 冷却器, 貯槽, バルブ 1, バルブ 2 およびこれらを連結 する配管(液上昇管, 液下降管等)から構成されている. 各構成要素について詳述すると, 加熱器は箱型容器 (底面: $240 \mathrm{~mm} \times 250 \mathrm{~mm}$, 高さ: $200 \mathrm{~mm}$, 肉厚: 5.0 $\mathrm{mm})$ の底部に, 温熱源として最大発生熱量 $2.0 \mathrm{~kW}$ のパ イプヒータを取り付けたものである. 一方, 冷却器は銅管 (内径: $20.2 \mathrm{~mm}$, 肉厚: $1.0 \mathrm{~mm}$, 長さ: $9.5 \mathrm{~m}$ )をコイル状 に巻いたものであり, 所定温度に保たれた恒温槽内の 冷水と熱交換される.ここで, 恒温槽内の水面からパイ プヒータ上面までの高さは $3.0 \mathrm{~m}$ である. 貯槽は箱型容 器(底面: $300 \mathrm{~mm} \times 400 \mathrm{~mm}$, 高さ: $150 \mathrm{~mm}$, 肉厚: 5.0 $\mathrm{mm})$ であり, バルブ 2 を介して加熱器へとつながる配管 を貯槽内に若干 $(20 \mathrm{~mm})$ 延長し, 常に底部に液溜まりが できるようにした. さらに, 深さ $5 \mathrm{~mm}$ の受液器も内部に 設け，液上昇管を通って流入する低温の作動液が受液 器内を滞留し, それよりオーバーフローした作動夜が貯 槽底部に貯液されるようにした. 以上の液溜まりには常 に $2.6 \mathrm{~kg}$ の作動液が溜まるようになっており, その設置 目的は貯槽内部における気液界面の面積を広くするた めである. 後述のようにバルブ 1 を開くと, 加熱器から貯 槽内部一高温の蒸気が流入するが,この時, 貯槽内に 貯液されている低温の作動液と十分に熱交換させて蒸 気を凝縮させ, 貯槽内の圧力が上昇するのを防止する ためである. 配管の内径は $16 \mathrm{~mm}$ である. なお, 加熱器, 貯槽, 配管はステンレス材を用いて製作した. また, 加 熱器および貯槽の側面にはポリカーボネイト製の観察 空と採光空を取り付け, 加熱器および貯槽内の作動液 流動状態を常に観察しながら, 実験を実施できるように した. 実験装置全体には断熱材を施した.

作動夜には水を用いた. 真空ポンプにより実験装置 内の空気を引き出し, 内部を $32 \mathrm{~Pa}$ まで減圧した後, 作 動液 $12.1 \mathrm{~kg}$ を封入した.この時, 作動液の液面は, 液 上昇管側, 液下降管側ともに, 加熱器内のパイプヒータ 上面より上方 $50 \mathrm{~mm}$ に位置している.

実験は, 前述の作動原理( i ) (iv)に基づき, 次の 手順で実施した. まず, バルブ 1 およびバルブ 2 を閉じ た状態で, パイプヒータにより加熱器内に熱を入力した. 加熱器内では作動液の温度が上昇し, 蒸気圧が高くな ると, 加熱器内の作動液は冷却器へと押し下げられる. 同時に, 冷却器内で泠却された作動液は貯槽一と押し 上げられる. 次に, 加熱器内の液面がパイプヒータの上 面まで低下すると, バルブ 1 およびバルブ 2 を同時に 開いた. 加熱器内の高温の蒸気が貯槽内部一流入し, 加熱器内と貯槽内が等圧になるので, 貯槽内に貯液さ れた作動液が重力により加熱器内一と還流される. 還流

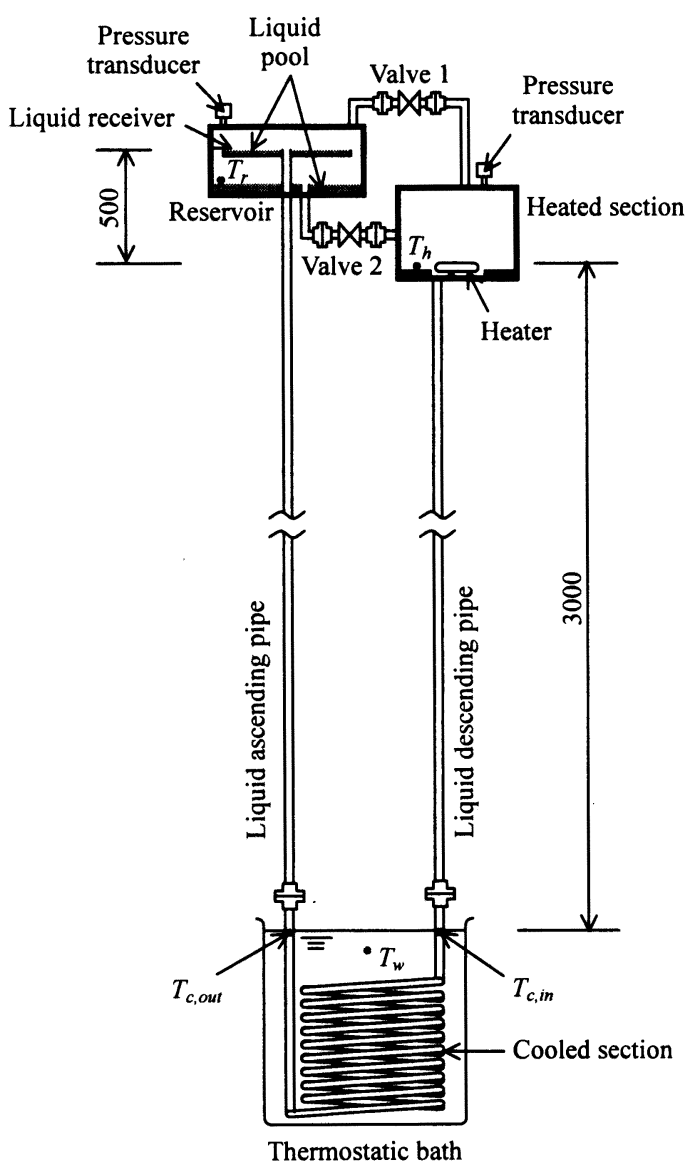

Fig. 2 Schematic diagram of the experimental apparatus

後, バルブ 1 およびバルブ 2 を同時に閉じ, 以上の手 順を繰り返した。 なお, 作動液封入時と同じく, 還流直 後は, 作動液の液面はパイプヒータ上面より上方 50 $\mathrm{mm}$ に位置しており,一周期の間に $3.0 \mathrm{~kg}(3.0 \mathrm{~L})$ の作 動液が加熱器から押し下げられる.これにより, 冷却器 に同量の作動液が流入するが, 本実験では, 作動液が 十分に冷却されるように, 冷却器の容積を $3.0 \mathrm{~L}$ として おり, 冷却器に流入した作動液は, 冷却器内を滞留し, 熱輸送ループの次の周期的な作動によって, 冷却器を 流出し, 貯槽へと押し上げられる. また, 作動液の還流 に関係するパイプヒータ上面から液上昇管上端までの 高さは $500 \mathrm{~mm}$ である.

本実験では, バルブの開閉操作を確実に行うため, バルブ 1, バルブ 2 ともに手動で操作した. なお, 本熱 輸送ループの実用化に際しては, 従来のトップヒート型 


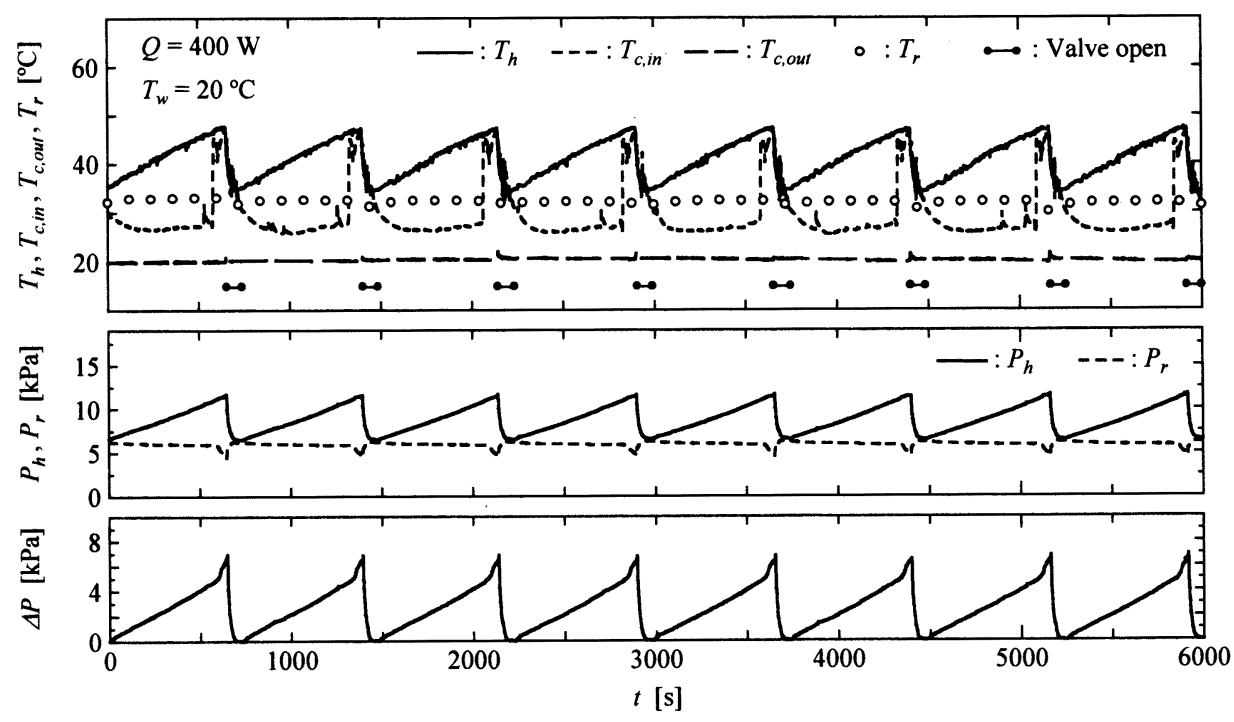

Fig. 3 Transient variations of temperatures, pressures and pressure difference in the heat transport loop

熱サイフォンで使用されているように, バルブ 1 にはフロ 一ト弁 ${ }^{(4),(5)}$ やごくわずかの電力を要するが, 電磁弁を 使用することが, 一方, バルブ 2 には逆止弁を使用する ことが推奨される.

実験条件として, パイプヒータによる加熱器への入熱 量 $Q$ を $200 \sim 1000 \mathrm{~W}$ に, 恒温槽内の水温 $T_{w}$ を 15,20 , $25^{\circ} \mathrm{C}$ に変化させ, 加熱器内液温度 $T_{h}$, 冷却器入口液 温度 $T_{c, i n}$, 冷却器出口液温度 $T_{c, \text { out }}$, 貯槽内液温度 $T_{r}$ の経時変化を $\mathrm{T}$ 型熱電対を用いて, 加熱器内圧力 $P_{h}$, 貯槽内圧力 $P_{r}$ の経時変化を圧力変換器を用いて測定 した. なお, 加熱器および貯槽については, 液温度の測 定と同時に蒸気温度の測定も行い,これらの差も算出し た. 加熱器の場合, 平均 $0.4{ }^{\circ} \mathrm{C}$, 最大 $1.0^{\circ} \mathrm{C}$ で液温度 の方が高く, また貯槽の場合, 平均 $1.0^{\circ} \mathrm{C}$, 最大 $3.0^{\circ} \mathrm{C}$ で蒸気温度の方が高かったが，いずれの温度差もわず かであることから, 本報では, 加熱器内液温度, 貯槽内 液温度を用いて検討を行う. また, 作動液の還流時間(= 両バルブを開いている時間)は, $90 \mathrm{~s}$ で一定とした。

\section{5. 实臨結果および考察}

$5 \cdot 1$ 基本的熟䑳送特性 代表的な実験条件 $(Q=$ $\left.400 \mathrm{~W}, T_{w}=20^{\circ} \mathrm{C}\right)$ における温度 $T_{h}, T_{c, \text { in }}, T_{c, \text { out }}, T_{r}$ およ び圧力 $P_{h}, P_{r}$ の経時変化を, 次式で定義したループ内 に生じる圧力差 $\Delta P$ とともに図 3 に示した。

$$
\Delta P=P_{h}-P_{r}
$$

また図中には, バルブ 1 およびバルブ 2 が開いている 時間(両者は $90 \mathrm{~s}$ で同一)も示した.

温度, 圧力, 圧力差は, バルブの開閉操作と対応し て周期的な変動を繰り返し, 本熱輸送ループが連続し て作動していることが確認できる. 各周期においては, 前述した作動原理に基づいて温度および圧力が変化 する. すなわち, パイプヒータからの熱により $T_{h}$ が上昇し て $P_{h}$ が高くなり, バルブ 1 およびバルブ 2 が閉じている ので, 加熱器内で加熱された作動液は泠却器へ向かっ て押し下げられる.このとき加熱器内では, しだいにパイ プヒータの伝熱面過熱度が大きくなるので, 通常のプー ル沸騰と同様に, 蒸気泡が発生して沸騰が激しくなる. このため, ループ内を流れる作動液の流量は多少変動 し, その時間平均値は増加する. 加熱された作動液が 冷却器入口まで到達すると $T_{c, i n}$ は急激に上昇するが, 作動液の流量が変動しているため, $T_{c, i n}$ にも $5{ }^{\circ} \mathrm{C}$ 程度 の変動が現れる. また, 冷却器内で $T_{c, \text { out }}$ まで泠却され た作動液が押し上げられて貯槽に流入し始めると，その 作動液は, まず, 受液器内に溜まっている作動液を冷 却し, 次に, 受液器よりオーバーフローして, 貯槽底部 に溜まっている作動液を冷却する.これにより, 貯槽内 の蒸気の凝縮が促進され, $P_{r}$ が低下する. なお図 3 か ら, 貯槽に流入した作動液は約 $150 \mathrm{~kJ}$ を受熱していると 計算でき, また, $P_{r}$ の低下に対応する蒸気の凝縮熱量 を求めると $0.4 \mathrm{~kJ}$ 程度となることから, 貯槽に流入した作 動液は液溜まりおよび貯槽容器から, そのほとんどの熱 
を受けていると考えられる. 加熱器内の液面がパイプヒ 一夕の上面まで低下すると, バルブ 1 およびバルブ 2 が 開かれるので, $P_{h}$ と $P_{r}$ が等しくなる. このとき, $P_{r}$ はわず かしか上昇せず, その後は極めて緩やかに低下するこ とが確認されるが,これは, バルブが開かれることにより 加熱器から貯槽へ流入する蒸気が, 貯槽に貯液された 低温の作動液によって冷却され，凝縮するためである. 前述のようにして貯槽内に液溜まりを設けた効果が現れ ていると考えられ， $P_{h}$ および $P_{r}$ が上昇し続けることなく 作動することから，本熱輸送ループは長期にわたる運転 が可能である. 貯槽に貯液された低温 $T_{r}$ の作動液が加 熱器へと還流されると, $T_{h}$ は一気に低下し, その後, バ ルブ 1 およびバルブ 2 が閉じられると, 同様の経時変化 が繰り返される.

前述のように図 3 から, 貯槽に流入した作動液は約 $150 \mathrm{~kJ}$ を受熱していると計算できるが, この熱は, バル ブ 1 およびバルブ 2 が開かれている時に, 蒸気流として 加熱器から輸送されたものである. なお, 本熱輸送ルー プは, 装置表面から周囲への熱損失を無視すると, 加 熱器および冷却器を除いて断熱系であり，また，系内の 温度および圧力は上昇または下降し続けることなく周期 的に変動する. したがって熱収支から, 蒸気流として加 熱器から貯槽へ熱が輸送されるものの, その熱は作動 液の還流とともに加熱器に戻っており, 加熱器へ入熱さ れた熱は熱損失分を除いて全て冷却器で放熱されてい ると考えられる.

本熱輸送ループでは, 真空ポンプによってループ内 の空気を引き出し, その後, 作動液を封入して操作して いるため, $P_{h}$ および $P_{r}$ はそれぞれ，温度 $T_{h}$ および $T_{r}$ に おける飽和蒸気圧とほぼ一致する.したがって, 任意の 時間における $T_{h}$ と $P_{h}, T_{r}$ と $P_{r}$ の関係は, 蒸気圧曲線を 用いて図 4 に示したように表され, また, 加熱器と貯槽 の温度差 $\Delta T_{h-r}$ を,

$$
\Delta T_{h-r}=T_{h}-T_{r}
$$

と定義すると, $\Delta T_{h-r}$ と式(1)の $\Delta P$ は, 図 4 に示したよう に関係づけられる. なお, $\Delta P$ については, 後掲 5.3 節 において詳しく検討する.

$T_{c, \text { out }}$ が $T_{w}$ にほぼ等しくなっていることから, 冷却器内 において作動液が十分に泠却されていることが確認で きる. また, 図 3 について, 次式で定義した貯槽と冷熱 源の温度差 $\Delta T_{r-w}$ を求めると, 平均 $12.2{ }^{\circ} \mathrm{C}$ となる.

$$
\Delta T_{r-w}=T_{r}-T_{w}
$$

$5 \cdot 2$ 熱輸送特性に及ほす諸因子の影霎 本熱輸 送ループの熱輸送特性に及ぼす, 入熱量 $Q$ および冷

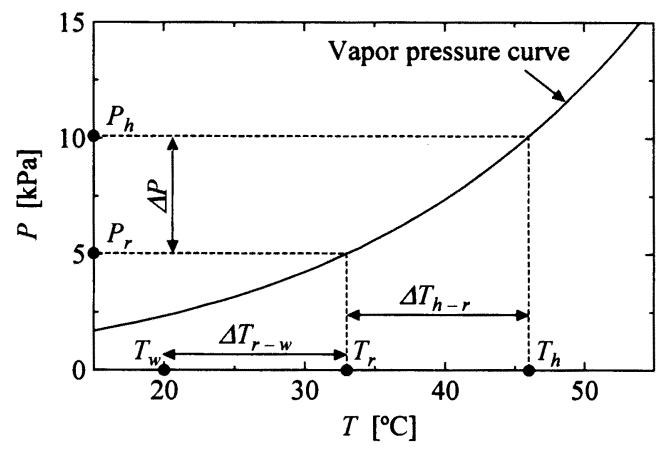

Fig. 4 Relation between temperatures and pressures inside the heat transport loop

熱源温度 $T_{w}$ の影響について検討する.

5·2・1 入熱量の影電 $Q=200,800 \mathrm{~W}$ に設定し た時の $T_{h}, T_{c, \text { out }}$ および $P_{h}, P_{r}$ の経時変化を図 5 に示し た. 図 3 と同様に, 温度および圧力は周期的に変動し, $T_{c, \text { oul }}$ は $T_{w}$ にほぼ等しくなっていることが確認できる. $Q$ の増加にほぼ比例して, 加熱器内での作動液蒸発速度 が増加するので, 加熱器から冷却器を経由して貯槽へ と流れる作動液の流量も増加する.したがって, 所定量 $(3.0 \mathrm{~kg})$ の作動液が加熱器から流出する時間, すなわち, 温度および圧力の変動周期 $t_{c y c l e}$ は流量に反比例する ため, 図 6 に示したように, $t_{\text {cycle }}$ も $Q$ にほぼ反比例して 変化する. しかしながら, $Q$ が変わっても, 加熱器内では ほぼ同一温度で作動液の沸騰が開始され, $T_{h}$ の変動域 はほとんど変化しないことが確認された。

熱輸送ループ作動時の $Q$ のステップ的な変化に対 する温度および圧力の応答を図 7 に示した. 図 5 と同 様に, $Q$ の変化に対して周期に影響が現れるものの, $T_{h}$ の変動域はほぼ固定され，熱輸送ループが作動してい ることがわかる.したがって, 顕熱のみを利用して熱輸送 を行う従来の単相流体ループと異なり，本熱輸送ルー プでは, 動作温度に及ぼす熱源の負荷変動の影響が 非常に小さいといえる.

$5 \cdot 2 \cdot 2$ 冷熟源温度の影霓 $T_{w}=15,25^{\circ} \mathrm{C}$ に設定 した時の $T_{h}, T_{\text {cout }}$ および $P_{h}, P_{r}$ の経時変化を図 8 に示 した. $T_{w}$ が高くなると, 温度および圧力は全体的に高く なり，図 4 の蒸気圧曲線からわかるように, $T_{h}$ の上昇に 対する $P_{h}$ の増加割合が大きくなる. したがって, 図 6 か ら確認できるように, $T_{w}$ が高くなると $t_{c y c l e}$ は若干短くなり, さらに, 温熱源と冷熱源の温度差が小さくなる.

5.3 熱輸送ループ内の圧力差 $\Delta P$ は $P_{h}$ と $P_{r}$ の 差であり, この圧力差によって加熱器内の作動液は下 部の冷却器へと押し下げられ, 同時に, 冷却器内の作 


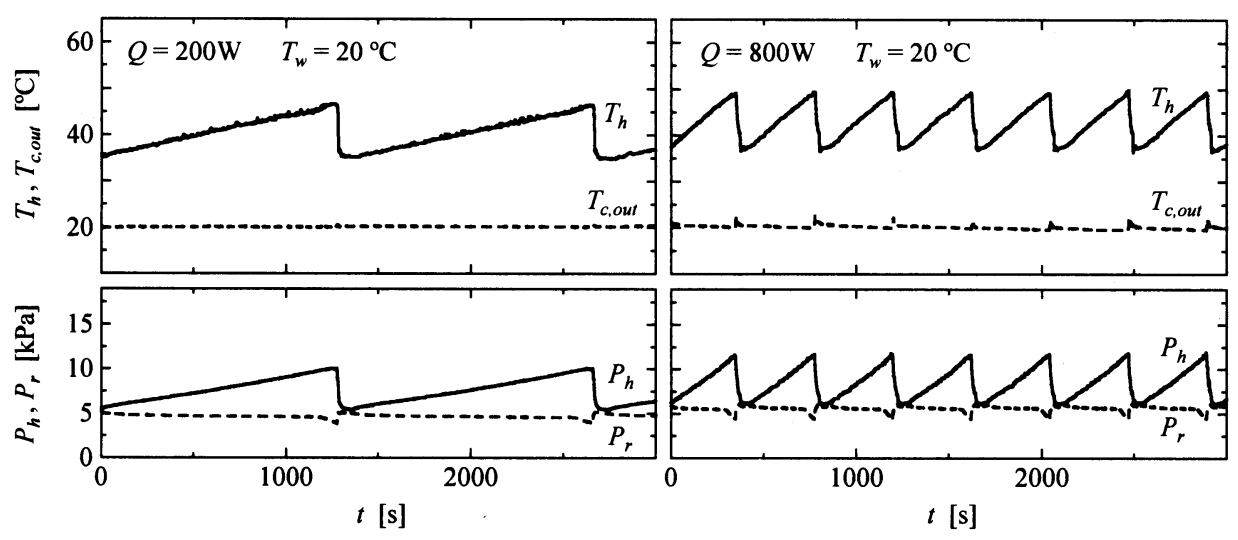

Fig. 5 Effect of heat input on the heat transport characteristics of the heat transport loop

動液は上部の貯槽へと押し上げられる. また, 図 4 に示 したように, 加熱器と貯槽の温度差 $\Delta T_{h-r}$ は $\Delta P$ によって 決まるので, $\Delta P$ は本熱輸送ループの動作温度を決定 する重要な因子の一つである.

図 3 に示した $\Delta P$ の経時変化について説明する. 還 流のため, バルブ 1 およびバルブ 2 が開かれると, 液上 昇管側と液下降管側の液位差 $\Delta h=0 \mathrm{~mm}, \Delta P=0 \mathrm{kPa}$ となり, バルブ 1 およびバルブ 2 が閉じられると, 作動液 が流動するので, $\Delta h$ の增加とともに $\Delta P$ が大きくなる. 前 述のように, 冷却器内で $T_{c, o u t}$ まで泠却された作動液が 押し上げられて貯槽に流入し始めると, $P_{r}$ が若干低下 寸るので, $\Delta P$ の増加率は大きくなり, さらに, バルブ 1 およびバルブ 2 が開かれる直前, すなわち, 加熱器内 の液面がパイプヒータの上面まで低下したとき, $\Delta h$ は最 大(最大值 $\left.\Delta h_{\text {max }}=500 \mathrm{~mm}\right)$ となり, 同時に $\Delta P$ も最大とな る.

全実験範囲における $\Delta P$ の最大值 $\Delta P_{\text {max }}$ を図 9 にまと めた. 従来のトップヒート型熱サイフォンと異なり, 本熱輸 送ループでは, 加熱器内のパイプヒータより以下は, 液 上昇管側, 液下降管側ともに, 作動液で常時満たされ ているため, 加熱器から貯槽までの高さが作動液の揚 液高さとなる. したがって, 本熱輸送ループは, 熱輸送 高さ(=冷却器から加熱器までの高さ)に対して, 揚液高 さが非常に小さく, ループ内に生じるわずかな圧力差で 作動する. また, ループ内での作動液の流動抵抗を無 視すると, $\Delta P_{\text {max }}$ は次式で表される.

$$
\Delta P_{\max }=\rho g \Delta h_{\max }
$$

ここで, $\rho$ は作動液の密度, $g$ は重力加速度であり, 式

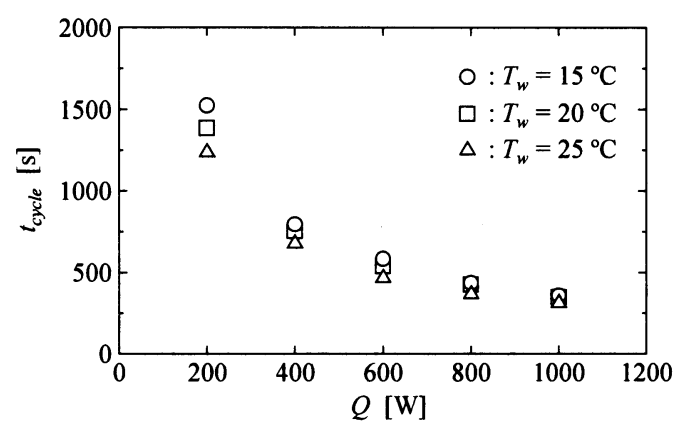

Fig. 6 A period of one temperature-pressure variation

(4)に $\Delta h_{\text {max }}=500 \mathrm{~mm}$ を代入すると, $\Delta P_{\text {max }}=4.9 \mathrm{kPa}$ が 得られることから, 図 9 中に $\Delta P_{\text {max }}=4.9 \mathrm{kPa}$ を破線で示 した.

$\Delta P_{\text {max }}$ は $T_{w}$ にほとんど依存しないことがわかる. また, 本熱輸送ループでは作動液の流動抵抗を伴うため, $\Delta P_{\text {max }}$ の実験值は $\Delta P_{\text {max }}=4.9 \mathrm{kPa}$ よりもやや大きくなるが， $Q$ が小さくなり,ループ内を流れる作動液の流量が减少 して, 流動抵抗が軽减されると, $\Delta P_{\text {max }}$ の実験值は $\Delta P_{\text {max }}$ $=4.9 \mathrm{kPa}$ に近づくことが確認できる. したがって, 配管 内径を大きくするなどして, 作動夜の流動抵抗をさらに 軽減すれば, $\Delta P_{\text {max }}$ は式(4)からほぼ決定されると予想さ れ, 本熱輸送ループは熱輸送高さに関係無く, 熱を下 向きに輸送できる.

\section{6. 結}

水の蒸気圧を利用して, 外部動力を要することなく, 

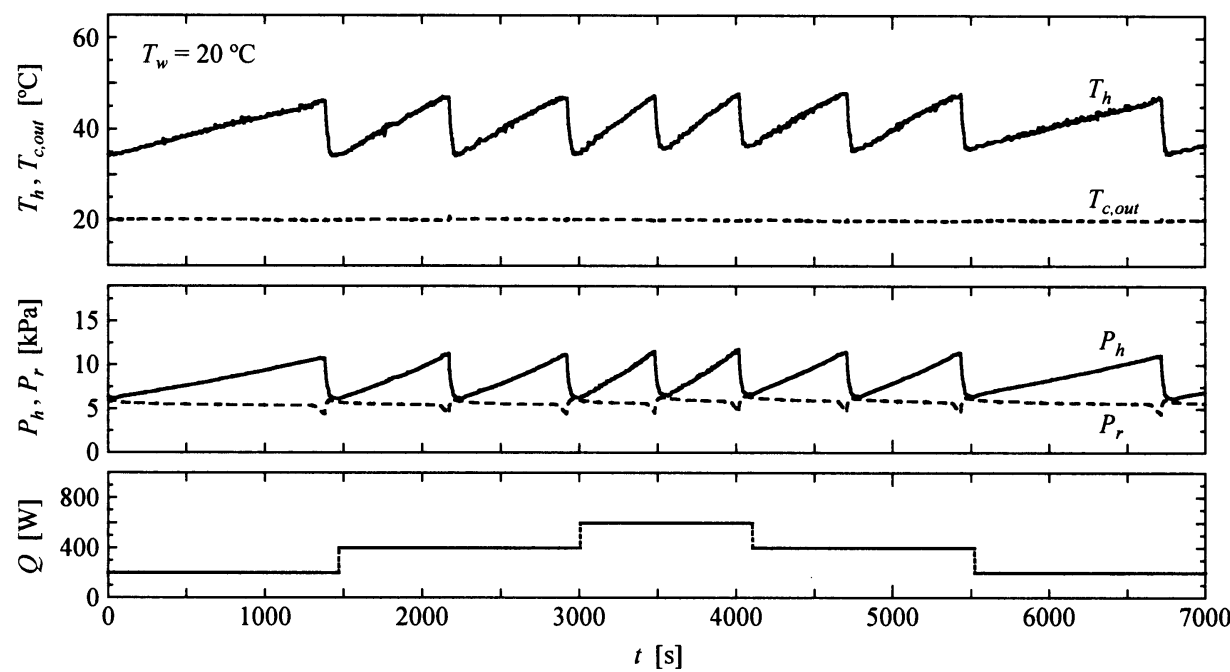

Fig. 7 Response of the heat transport loop for sudden change in heat input
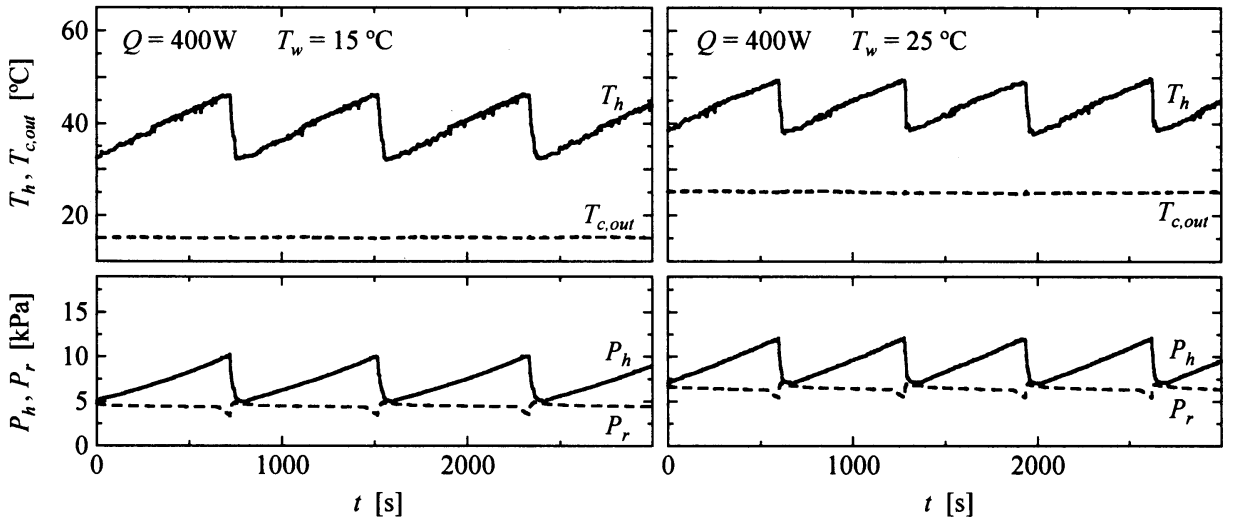

Fig. 8 Effect of cooling temperature on the heat transport characteristics of the heat transport loop

熱を下方に輸送する熱輸送ループを新たに構築した. 温熱源の熱量および泠熱源の温度を変化させて熱輸 送特性に関する基礎実験を行い, 次の結論を得た.

(1) 本熱輸送ループは, バルブの開閉に伴う温度お よび圧力の周期的な変動とともに, 熱を下方に輸送する.

(2) 加熱器内で発生した蒸気は, 作動液の還流時に 貯槽に流れ，低温の作動液と熱交換して凝縮するので， ループ内の圧力は上昇し続けることなく作動する. した がって, 本熱輸送ループは長期にわたる運転が可能で ある.
（3）温度および圧力の変動周期は, 温熱源の熱量に ほぼ反比例して変化する. しかしながら, 従来の単相熱 輸送ループと異なり, 温熱源の熱量が変わっても, 加熱 器内ではほぼ同一温度で作動液の沸騰が開始されるた め, 本熱輸送ループの動作温度はほとんど変化しない ことが確認された.

(4) 冷熱源の温度が変わると, 温度と圧力の変動周 期および温熱源と冷熱源の温度差に若干の影響が現 れる.これは, 蒸気圧曲線からわかるように, 作動液の 温度によって, 温度変化に対する蒸気圧の変化割合が 
異なるためである.

(5) 従来のトップヒート型熱サイフォンと異なり, 加熱 器から貯槽までの高さが作動液の揚液高さとなる. した がって, 本熱輸送ループは, 熱輸送高さに対して, 揚液 高さが非常に小さく, ループ内に生じるわずかな圧力差 で作動する.

(6) ループ内での作動液の流動抵抗をさらに軽减す れば, 本熱輸送ループは熱輸送高さに関係無く, 熱を 下向きに輸送できる.

\section{謝辞}

本研究を遂行するにあたり, 熊本大学工学部技術部 有吉剛治 氏, 熊本大学大学院自然科学研究科学生 原田俊亮 君に協力をいただいた.ここに記して謝意を 表する。

\section{文献}

(1) Imura, H. and Koito, Y., Heat Transport Using Top-heattype Thermosyphons, Nihon Reito Kucho Gakkai Ronbunshu (Transactions of the Japan Society of Refrigerating and Air Conditioning Engineers), 22-1 (2005), 1-12.

(2) Maidanik, Yu. F. et al., Development, Analytical and Experimental Investigation of Loop Heat Pipes, Proceedings of the 7 th International Heat Pipe Conference, II (1990), 539-546.

(3) Borodkin, A. et al., Experimental Investigation and Analytical Modelling of an Autooscillation Two-phase Loop, Proceedings of the 9th International Heat Pipe Conference, I (1995), 30-35.

(4) Hashimoto, N. et al., Top Heat Type Heat Pipe, Proceedings of the 9th International Heat Pipe Conference, II (1995), 833-837.

(5) Kawabata, K. et al., Anti-gravity Heat Pipe, Proceedings of the 5th International Heat Pipe Symposium, (1996), 168175.

(6) Fantozzi, F. et al., Heat Transport Device Based on Pulsing

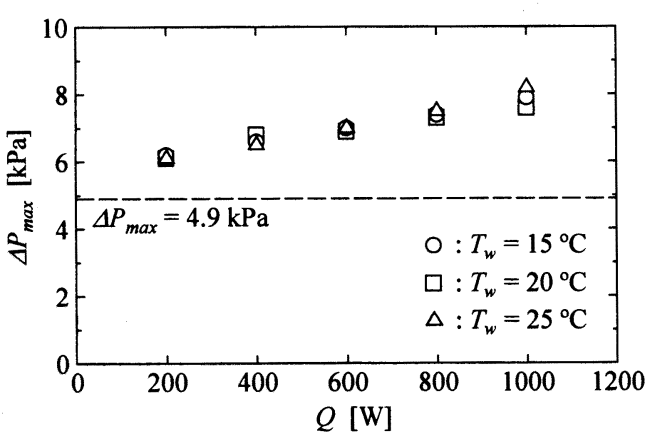

Fig. 9 Maximum pressure difference produced in the heat transport loop

Thermosyphons with Forced Fluctuations of Pressure, Proceedings of the 12th International Heat Pipe Conference, (2002), 469-474.

(7) Kadoguchi, K. and Yamazaki, M., Operating Limit of the Self-operative Heat Transfer Loop, Thermal Science \& Engineering, 11-4 (2003), 65-66.

(8) Chisholm, D., The Anti-gravity Thermosyphon, Multi-phase Flow Systems, 2, Institution of Chemical Engineers Symposium Series, No. 38 (1974), 1-17.

(9) Hirashima, M. et al., Experimental Study of Top Heat Mode Thermosyphon (On the Lifting Mechanism of Working Fluid Effects on the Extension of Stable Working Range), Nihon Reito Kyokai Ronbunshu (Transactions of the Japanese Association of Refrigeration), 10-2 (1993), 247256.

(10) Minning, C. P. et al., Development of an Osmotic Heat Pipe, Proceedings of the 3rd International Heat Pipe Conference, (1978), 327-334.

(11) Minning, C. P. et al., Design and Test of a Prototype Osmotic Heat Pipe, Proceedings of the AIAA 14th Thermophysics Conference, (1979), 307-328.

(12) Basiulis, A. et al., Design, Development, and Test of a 1000 W Osmotic Heat Pipe, Proceedings of the AIAA 15th Thermophysics Conference, (1980), 324-344. 